\title{
Imperata cylindrica: a noxious weed of pharmacological potentials
}

\author{
P.B. Lalthanpuii, Zarzokimi, K. Lalchhandama* \\ ${ }^{1}$ Department of Life Sciences, Pachhunga University College, Mizoram University, Aizawl 796001, Mizoram, India
}

Corresponding author: chhandama@gmail.com

\begin{abstract}
Imperata cylindrica (L.) Räuschel (family Poaceae) is a perennial grass known in different traditional medicines in Southeast Asia for the treatment of a wide range of infectious diseases, particularly of bacterial infections. It is also used as an antifungal remedy in ringworms and other skin infections. It is ethnically unique to the Mizo tribes for the use of the leaves are as the main construction materials for thatched roofs in traditional houses, and the rhizome-roots are used directly as anthelmintic agents. Crushed and juiced, or directly chewed, they are consumed for the treatment of intestinal infection, and are known to be effective for both tapeworm and roundworm species. Practically nothing is known about its chemical and biological properties. A methanol extract was prepared using Soxhlet apparatus. A series of standard phytochemical screening was performed which indicated the presence of alkaloids, carbohydrates including reducing sugars, phytosterols, tannins, saponins and proteins as major bio-compounds. There are no indications of glycosides and flavonoids, which are usually important bioactive compounds in many medicinal plants. The antioxidant activities of the plant extract were assessed by free radicals scavenging assays using 2,2-diphenyl-1picrylhydrazyl (DPPH) and hydrogen peroxide $\left(\mathrm{H}_{2} \mathrm{O}_{2}\right)$. The plant extract showed concentration-dependent scavenging activity on DPPH with an inhibitory concentration $\left(\mathrm{IC}_{50}\right)$ of $2.14 \mu \mathrm{g} / \mathrm{ml}$. Similar activity was shown forscavenging $\mathrm{H}_{2} \mathrm{O}_{2}$, with an $\mathrm{IC}_{50}$ of $2.221 \mu \mathrm{g} / \mathrm{ml}$. These findings provide an evidence that $\mathrm{I}$ cylindrica has promising pharmacological properties that warrant further investigations.
\end{abstract}

Keywords: Imperata cylindrica, phytochemicals, antioxidant, free radicals, DPPH, $\mathrm{H}_{2} \mathrm{O}_{2}$.

\section{INTRODUCTION}

Imperata cylindrica (L.) Räuschel (family Poaceae) is a long-lived rhizomatous grass that is native to the Indomalayan and Australasian realms. It is well known in different traditional medicines throughout Southeast Asia for the treatment of a wide range of infectious diseases. It is also a valued construction material for thatching in many Asian tribal communities due to its resilient fibre. In addition, the leaves have been used for making papers, weaving mats, bags, and organic raincoats. A variety grown in the Far East is used as an ornamental grass; most famously as Red Baron or Japanese Blood grass. The flowers and roots have been known to have antibacterial, diuretic, skin softening (emollient), antipyretic (febrifuge), salivating (sialagogue), anticoagulant (styptic) and soothing (tonic) properties (Townson, 1991). The roots are used for treatment of nosebleed (epistaxis), blood urine (haematuria), blood vomit (haematemesis), oedema, and jaundice. Some compounds from the leaves have neuro-protective (Yoon et al., 2006), and vasodilative effects (Matsunaga et al., 1994).

I. cylindrica is a perennial weed, thin leafed, and elongated. The total height varies from $30-150 \mathrm{~cm}$. The aerial part is erect and arises from the rhizomes. The aerial part is mostly of the leaves, as the stem (culm) is relatively short. The leaves are hard, linear-lanceolate, up to 120 $\mathrm{cm}$ long and 4-18 $\mathrm{mm}$ wide, with a prominent whitish midrib and pointed tip. The rhizomes are tough, highly branched, white in colour, variable in length and covered with papery scale-leaves at the nodes. They can be few centimetres to $1 \mathrm{~m}$ long. The roots are fibrous, whitish, and emerge from the base of the culm and the nodes on the rhizome. The inflorescence forms a spike-like panicle, is white in colour, fluffy, about $5-20 \mathrm{~cm}$ long and up to $2.5 \mathrm{~cm}$ in diameter. There are numerous spikelets, about 3.5-5.0 mm long, and each is surrounded by a basal ring 
of silky hairs $10 \mathrm{~mm}$ long. The grain is oblong, pointed, brown in colour, and 1-1.5 mm long (CABI, 2018).

The species was first described by a Swedish naturalist Carl Linnaeus in 1759 under the genus Lagurus as Lagurus cylindricus. A German botanist Ernst Adolf Räuschel redescribed it in 1797 and placed it under the genus Imperata, the genus of which was created by an Italian botanist Domenico Cirillo in 1792, by which Räuschel gave the name Imperata cylindrica. The common English vernacular name is "cogon grass"; with cogon derived from Spanish cogón, which in turn originated from the Tagalog kugon, simply meaning grass.

I. cylindrica is infamously nominated in the list of 100 "World's Worst" invaders by the IUCN Invasive Species Specialist Group. The Federal Noxious Weeds List from the United States Department of Agriculture also included it in list. It is known to be invasive in 73 countries and of about 35 crops with the most affected crops occurring in the tropical rainforests (CABI, 2018; Lusweti et al., 2011). The aggressive invasion is particularly extensive in West and Central Africa and in the United States, where vast stretches of farmlands are completely abandoned each year. This is due to its ability to compete with native plants for water and nutrients, and a wide range of adaptability under different environmental conditions (MacDonald, 2004; Koger and Bryson, 2017).

Among the Mizo people, the plant is known to have a good antibacterial activity and has been used in dermal wound, cholera, dysentery and diarrhoea. It is also used as dermal fungicide in ringworms and other skin infections. The Mizo called it di. It is traditionally unique to the Mizo tribes because the leaves are utilised as the main materials for thatched roofs in Mizo houses, and the roots are used directly as anthelmintic agents for the treatment of intestinal infection (Sawmliana, 2013). The roots crushed and juiced, or directly chewed, are directly consumed for intestinal infection. They are known to be equally effective for expelling both tapeworm and roundworm species. The propagation of the plant is usually spurred by forest fires and burning for slash-and-burn (jhum) cultivation during summer in Mizoram.

\section{Materials AND MethodS}

\section{Plant material}

The rhizomes and roots of I. cylindra were collected in January 2018 from Ngopa village, Champhai district, Mizoram, India (located between $23.8861^{\circ}$ latitude north and $93.2119^{\circ}$ longitude east). Only the fully mature and flowering plants were selected. A voucher specimen was identified at the Botanical Survey of India (BSI), Shillong, Meghalaya, and is maintained at the herbarium section of the Department of Botany, Pachhunga University College, Aizawl, Mizoram (accession no PUC-I-2018-01). The roots were dried in shade at room temperature ranging from $21-27^{\circ} \mathrm{C}$.

\section{Preparation of plant extracts}

The dried roots were weighed and recorded, and then they were pulverised to powder using mortar and pestle. A pre-weighed dust was loaded into the thimble of Soxhlet apparatus having a $5 \mathrm{~L}$ capacity. The plant was subjected to continuous hot extraction using methanol as a solvent. The extracts were concentrated by recycling the solvents in a vacuum rotary evaporator (Buchi Rotavapor $^{\circledR}$ R-215). The crude plant extracts were produced in the form of semi-solid mass, and were refrigerated at $4^{\circ} \mathrm{C}$ until further use.

\section{Phytochemical detection}

The chemical constituents of I. cylindra were screened using standard protocols. Alkaloids were tested by Mayer's test, Dragendorff's test, Wagner's test and Hager's test; carbohydrates by Molisch's test, Fehling's test and Benedict's test; phytosterols by LiebermannBurchard's test and Salkwoski reaction; glycosides by Legal's test, Baljet's test and Borntrager's test; tannins by iron(III) chloride $\left(\mathrm{FeCl}_{3}\right)$ test, potassium dichromate $\left(\mathrm{K}_{2} \mathrm{Cr}_{3} \mathrm{O}_{7}\right)$ test and lead acetate test; saponins by foam test; reducing sugars by Fehling's test and Benedict's test; flavonoids by Shinoda test and zinc hydrochloride (ClHZn) reduction test; and proteins/amino acids by Millon's test and ninhydrin test.

\section{DPPH-scavenging activity}

The antioxidant activity was estimated in terms of the capacity to scavenge a stable free radical DPPH $(2,2-$ diphenyl-1-picrylhydrazyl) after the method of Blois (1958). In brief, different concentrations of the plant extract such as $10,20,40,60,80$, to $100 \mu \mathrm{g} / \mathrm{ml}$ were prepared by dissolving in distilled water. A final volume of 3 $\mathrm{ml}$ was made for each concentration using methanol, to which $0.5 \mathrm{ml}$ of DPPH solution was added. For the standard reference, butylated hydroxytoluene (BHT) was prepared in similar concentrations as that of the extracts. Control sample consisted of $3 \mathrm{ml}$ of methanol with $0.5 \mathrm{ml}$ of DPPH solution. All assays were performed in triplicate. They were incubated at $37 \pm 1^{\circ} \mathrm{C}$ for 30 minutes. Absorbance was measured at $517 \mathrm{~nm}$ against control using a UV -Vis spectrophotometer. The percentage of inhibition was calculated by comparing the absorbance values of the test samples with those of the controls.

The inhibition percentage (I\%) was calculated using the formula:

$$
\text { I\% of DPPH }=[(A C-A S) / A C] \times 100
$$

Where AC is the absorbance of control and AS is the absorbance of the sample or standard. 


\section{Hydrogen peroxide radical-scavenging assay}

The ability of I. cylindrica methanol extract to scavenge hydrogen peroxide was tested according to the method of Ruch et al. (1989). Ascorbic acid was used as a standard antioxidant. Briefly, $40 \mathrm{mM}$ of hydrogen peroxide was prepared in phosphate buffer $(\mathrm{pH}$ 7.4). Different concentrations $(10,20,40,60,80$, to $100 \mu \mathrm{g} / \mathrm{ml})$ of the extract and ascorbic acid were added separately to the hydrogen peroxide solution $(0.6 \mathrm{~mL}, 40 \mathrm{mM})$. After tenminute interval, the absorbance was taken at $230 \mathrm{~nm}$ against a blank solution containing the phosphate buffer without hydrogen peroxide.

The percentage of inhibition was calculated using the formula:

$$
\text { I\% of } \mathrm{H}_{2} \mathrm{O}_{2}=[(\mathrm{AC}-\mathrm{AS}) / \mathrm{AC}] \times 100
$$

Where $A C$ is the absorbance of control and AS is the absorbance of the sample or standard.

\section{RESULTS}

\section{Phytochemical analysis}

Standard chemical tests revealed important bioactive compounds in the rhizome extract of I. cylindrica as shown in Table 1. The occurrence of alkaloids, carbohydrates and reducing sugars, tannins, phytosterols and proteins/amino acids are confirmed. Mayer's test indicated the presence of alkaloids. Fehling's test and Benedict's test indicated the presence of. Salkwoski reaction showed the presence of phytosterols. $\mathrm{K} 2 \mathrm{Cr} 3 \mathrm{O} 7$ test and lead acetate test showed the presence of tannins. Millon's test showed the presence of proteins and amino acids. On the other hand, saponin, flavonoid and glycoside were not detected.

\section{DPPH-scavenging activity}

The antioxidant activity of the methanol extract of I. cylindrica estimated using DPPH-scavenging assay is shown in Figure 2. Increasing activity was observed from 10 to $100 \mu \mathrm{g} / \mathrm{ml}$ of the plant extract and the reference compound. Both the extract and BHT showed linear concentration-dependent activity against DPPH, i.e. increased scavenging activity with increased concentration. BHT appeared to be more potent than the plant extract at all concentrations tested. At the lowest and highest concentrations, the plant extract scavenged $46.35 \%$ and $62.11 \%$ of DPPH respectively; while BHT could scavenge $51.72 \%$ and $85.34 \%$ at the same concentrations. The inhibitory concentration, $\mathrm{IC}_{50}$ of the plant extract was calculated to be $2.22 \mu \mathrm{g} / \mathrm{ml}$, while that of BHT as $0.73 \mu \mathrm{g} / \mathrm{ml}$.
Table 1: Phytochemical analyses of the methanol extract of I. cylindrica rhizome.

\begin{tabular}{|c|c|c|c|}
\hline $\begin{array}{l}\text { Sl. } \\
\text { No. }\end{array}$ & Phytochemicals & Phytochemical test & Result \\
\hline \multirow[t]{4}{*}{1.} & \multirow[t]{4}{*}{ Alkaloids } & Mayer's test & + \\
\hline & & Dragendorff's test & - \\
\hline & & Wagner's test & - \\
\hline & & Hager's test & - \\
\hline \multirow[t]{3}{*}{2.} & \multirow[t]{3}{*}{ Carbohydrates } & Molisch's test & - \\
\hline & & Fehling's test & + \\
\hline & & Benedict's test & + \\
\hline \multirow[t]{2}{*}{3.} & \multirow[t]{2}{*}{ Phytosterols } & $\begin{array}{l}\text { Liebermann-Burchard's } \\
\text { test }\end{array}$ & - \\
\hline & & Salkwoski reaction & + \\
\hline \multirow[t]{3}{*}{4.} & \multirow[t]{3}{*}{ Glycosides } & Legal's test & - \\
\hline & & Baljet's test & - \\
\hline & & Borntrager's test & - \\
\hline \multirow[t]{3}{*}{5.} & \multirow[t]{3}{*}{ Tannins } & $\mathrm{FeCl}_{3}$ test & - \\
\hline & & $\mathrm{K}_{2} \mathrm{Cr}_{3} \mathrm{O}_{7}$ test & + \\
\hline & & Lead acetate test & + \\
\hline 6. & Saponins & Foam test & + \\
\hline \multirow[t]{2}{*}{7.} & \multirow[t]{2}{*}{ Reducing sugars } & Fehling's test & + \\
\hline & & Benedict's test & + \\
\hline \multirow[t]{2}{*}{8.} & \multirow[t]{2}{*}{ Flavonoids } & Alkaline reagent test & - \\
\hline & & $\mathrm{ClHZn}$ reduction test & - \\
\hline \multirow[t]{2}{*}{9.} & \multirow{2}{*}{$\begin{array}{l}\text { Proteins/amino } \\
\text { acids }\end{array}$} & Millon's test & + \\
\hline & & Ninhydrin test & - \\
\hline
\end{tabular}

\section{$\mathrm{H}_{2} \mathrm{O}_{2}$-scavenging activity}

The $\mathrm{H}_{2} \mathrm{O}_{2}$-scavenging activity of the methanol extract of I. cylindrica is given in Figure 2. A concentrationdependent effect was apparent in the scavenging activity. The highest scavenging activity was shown by $100 \mu \mathrm{g} /$ $\mathrm{ml}$ which scavenged $-85.71 \%$ of, while the lowest scavenging activity was shown by $10 \mu \mathrm{g} / \mathrm{ml}$ that scavenged $91.43 \%$ of $\mathrm{H}_{2} \mathrm{O}_{2}$. Ascorbic acid scavenged $-100 \%$ and $84.62 \%$ at $100 \mu \mathrm{g} / \mathrm{ml}$ and $10 \mu \mathrm{g} / \mathrm{ml}$ respectively. The $\mathrm{IC}_{50}$ of the plant extract was $2.57 \mu \mathrm{g} / \mathrm{ml}$, while that of the standard ascorbic acid was $2.1 \mu \mathrm{g} / \mathrm{ml}$, revealing that they are almost equally efficacious.

\section{DISCUSSION}

In this study, important phytochemicals were detected such as alkaloids, carbohydrates including reducing sugars, phytosterols, tannins, saponins and proteins as the major bio-compounds of I. cylindrica. The biological and medical importance of these compounds are wide ranging and extensive. Alkaloids, phytosterols, and saponins are known to be among the crucial sources of pharmaceutical drugs. Plant alkaloids have provided us commercially valuable drugs including antimalarial (quinine), antihistamine (ephedrine), anticancer (homoharringtonine), vasodilatory (vincamine), antiar- 
Figure 1: DPPH-scavenging activity of $I$. cylindrica and butylated hydroxytoluene.

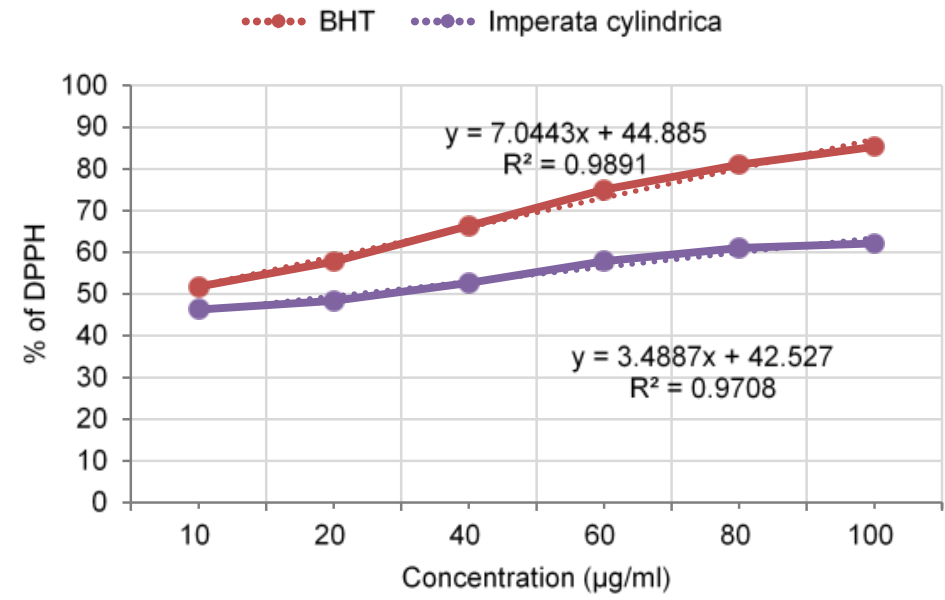

Figure 2: $\mathrm{H}_{2} \mathrm{O}_{2}$-scavenging activity of $I$. cylindrica and ascorbic acid.

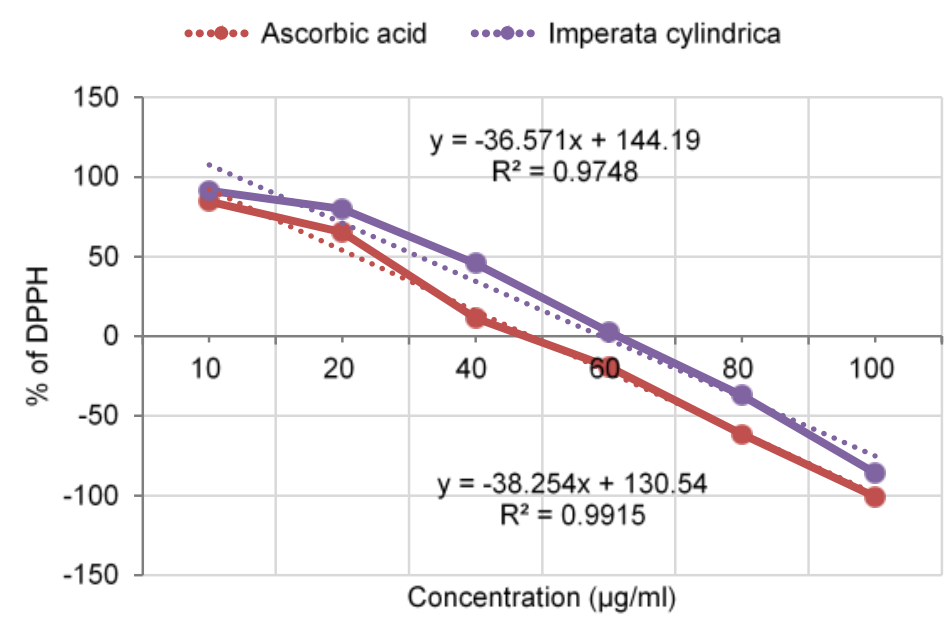

rhythmic (quinidine), analgesic (morphine), antibiotic (chelerythrine), antihyperglycaemic (piperine) drugs, as well as psychotropic (psilocin), and stimulant compounds (cocaine, caffeine, nicotine, theobromine) (Cordell et al., 2001). Phytosterols are proven to be potent modulators of the immune system and prevent cellular malfunctions that can erupt into cancer and autoimmune disorders. They are most successfully used as cholesterol-reducing agents (Bouic, 2001). Saponins are established to have a wide range of biological activities including antidiabetic, expectorant, antiinflammatory, vasoprotective, hypocholesterolemic, immunomodulatory, hypoglycaemic, molluscicidal, antifungal, and antiparasitic activities (LacailleDubois and Melzig, 2016).

Free radicals like reactive oxygen and nitrogen species are produced by the normal cellular metabolic processes in the body, and as such they are affirmed to be the major causes of inherent molecular damage to DNA, lipids, proteins, and other vital biomolecules. Free radicals often seize electrons from biomolecules making them structurally and functionally altered (Sies et al., 2017). Chemicals like hydrogen peroxide has been known to have the capability to cross plasma membranes and oxidize cellular compounds such as nucleic acids, lipids, proteins resulting in the inactivation of certain genes (Gaschler and Stockwell, 2017). The overall effect called oxidative stress is therefore deeply linked with several gene-based diseases including those of as cardiovascular, neurodegenerative, cancer and even aging (LópezAlarcón and Denicola, 2013). Our immune system is not equipped with sufficient defense mechanism to ameliorate all the adverse effects of such endogenous oxidants.

Antioxidants and antioxidant enzymes are a large group of bioactive compounds that are important for maintaining the oxidation equilibrium in a biological system, and they do this by effectively promoting the elimination of free radicals which are constantly produced as a result of cellular oxidative stress. Our body has special antioxidant defenses such as superoxide dismutases, hydrogen peroxide-removing enzymes, metal binding proteins, but which are inadequate to combat the overwhelming oxidation in the cells. This situation makes exogenous antioxidants crucial for curbing the oxidation hazards by converting the harmful free radicals to harmless molecules or by annihilating them (Das et al., 2017). The protective action of those molecules is not limited to 
scavenging the free radicals alone but also extends to upregulation of antioxidant and detoxifying enzymes, modulation of redox cell signaling and gene expression, thereby maintaining the body balance of oxidation and free radical removal (Pisoschi and Pop, 2015).

In this way, dietary antioxidants are one of the principle sources of defense for cellular oxidation (Wu e tal., 2017; Lorenzo et al., 2018). Medicinal plants in particular are among the best sources of these antioxidant compounds as they are readily available (Das et al., 2017; Lee et al., 2017). Therefore, understanding the power of plants to eliminate free radicals, i.e. their antioxidant potential, is a critical piece of investigation for recognising their therapeutic tendency. It is therefore obvious that compounds that can exert antioxidant effects on these free radicals and repress oxidative damage can prevent the formation of many debilitating diseases like cancer (Gholamian-Dehkordi et al., 2017; Meybodi et al., 2017). Our experiment shows that I. cylindrica has a high antioxidant activity, and in fact more potent than BHT, and equally potent as ascorbic acid. This indicates that the plant is a good source of free radical scavenger, which obviously has tremendous yet unexplored pharmacological potentials.

\section{ACKNOWLEDGEMENT}

The research is supported by Science and Engineering Research Board (SERB), Government of India, through research project no. EMR/2016/004053 of 23/03/2017. $\mathrm{PBL}$ is a Junior Research Fellow under the project.

\section{REFERENCES}

Blois, M.S. (1958). Antioxidant determinations by the use of a stable free radical. Nature, 181: 1199-1200.

Bouic, P. J. (2001). The role of phytosterols and phytosterolins in immune modulation: a review of the past 10 years. Current Opinion in Clinical Nutrition \& M etabolic Care, 4(6): 471-475.

CABI (2018). Imperata cylindrica (cogon grass). In: Invasive Species Compendium. www.cabi.org. Oxon (UK): CAB International, online.

Cordell, G. A., Quinn-Beattie, M. L., Farnsworth, N. R. (2001). The potential of alkaloids in drug discovery. Phytotherapy Research, 15(3): 183-205.

Das, U., Behera, S. S., Pramanik, K. (2017). Ethno-herbalmedico in wound repair: An incisive review. Phytotherapy Research, 31(4): 579-590.

Gaschler, M.M., Stockwell, B.R. (2017). Lipid peroxidation in cell death. Biochemical and Biophysical Research Communications, 482: 419-425.

Gholamian-Dehkordi, N., Luther, T., Asadi-Samani, M., Mahmoudian-Sani, M. R. (2017). An overview on natural antioxidants for oxidative stress reduction in cancers; a systematic review. Immunopathologia
Persa, 3(2): e12.

Koger, C.H., Bryson, C.T. (2017). Effect of Cogongrass (Imperata cylindrica) extracts on germination and seedling growth of selected grass and broadleaf species. Weed Technology, 18 (02): 236-242.

Lacaille-Dubois, M. A., Melzig, M. F. (2016). Saponins: Current progress and perspectives. Planta Medica, 82 (18): 1495-1495.

Lee, M. T., Lin, W. C., Yu, B., Lee, T. T. (2017). Antioxidant capacity of phytochemicals and their potential effects on oxidative status in animals-A review. AsianAustralasian Journal of Animal Sciences, 30(3): 299308.

López-Alarcón, C., Denicola, A. (2013). Evaluating the antioxidant capacity of natural products: A review on chemical and cellular-based assays. Analytica Chimica Acta, 763, 1-10.

Lorenzo, J. M., Munekata, P. E., Gómez, B., Barba, F. J., Mora, L., Pérez-Santaescolástica, C., Toldrá, F. (2018). Bioactive peptides as natural antioxidants in food products-A review. Trends in Food Science \& Technology, 79: 136-147.

Lusweti, A., Wabuyele, E., Ssegawa, P., Mauremootoo, J. (2011). Imperata cylindrica (Cogon Grass). keys.lucidcentral.org. BioNET-EAFRINET.

Matsunaga, K.; Shibuya, M., Ohizumi, Y. (1994). Graminone $B$, a novel lignan with vasodilative activity from Imperata cylindrica. Journal of Natural Products, 57 (12): 1734-1736.

MacDonald, G.E. (2004). Cogongrass (Imperata cylindrica)-Biology, ecology, and management. Critical Reviews in Plant Sciences, 23 (5): 367-380.

Meybodi, N. M., Mortazavian, A. M., Monfared, A. B., Sohrabvandi, S., Meybodi, F. A. (2017). Phytochemicals in cancer prevention: a review of the evidence. Iranian Journal of Cancer Prevention, 10(1): e7219.

Pisoschi, A. M., Pop, A. (2015). The role of antioxidants in the chemistry of oxidative stress: a review. European Journal of Medicinal Chemistry, 97: 55-74.

Ruch, R.J., Cheng, S.J., Klaunig, J.E. (1989). Prevention of cytotoxicity and inhibition of intercellular communication by antioxidant catechins isolated from Chinese green tea. Carcinogenesis, 10: 1003-1008.

Sawmliana, M. (2013). The Book of Mizoram Plants. Aizawl (India): P. Zakhuma, p. 143.

Sies, H., Berndt, C., Jones, D. P. (2017). Oxidative stress. Annual Review of Biochemistry, 86: 715-748.

Townson, J.K. (1991). Imperata cylindrica and its control. Weed Abstracts, 40 (11): 457-468.

Wu, X., Cheng, J., Wang, X. (2017). Dietary antioxidants: potential anticancer agents. Nutrition and Cancer, 69 (4): 521-533.

Yoon, J.S., Lee, M.K., Sung, S.H., Kim, Y.C. (2006). Neuroprotective 2-(2-phenylethyl) chromones of Imperata cylindrica. Journal of Natural Products, 69 (2): 290291. 